Available online at: http://openjournal.masda.ac.id/index.php/edumasda

Edu Masda Journal

ISSN (Print) 2597-4572 ISSN (Online) 2715-5269

\title{
AKTIFITAS KUNYIT (Curcuma domestica Val.) SEBAGAI ANTIINFLAMASI DITINJAU DARI BERBAGAI LITERATUR
}

Humaira Fadhilah", Karunia Rachmani, Nurihardianti Hajaring

STIKes Kharisma Persada, Pamulang, Tangerang Selatan, Indonesia

\begin{tabular}{|c|c|}
\hline ARTICLE INFORMATION & $A B S T R A C T$ \\
\hline $\begin{array}{l}\text { *Corresponding Author } \\
\text { Humaira Fadhilah } \\
\text { E-mail: humaira@masda.ac.id }\end{array}$ & \multirow{2}{*}{$\begin{array}{l}\text { Inflammation is a normal protective response to tissue injury caused by } \\
\text { physical trauma, damaging chemicals, or microbiological substances. } \\
\text { Steroids and nonsteroidal anti-inflammatory drugs have many side effects, so } \\
\text { there are many anti-inflammatory developments originating from natural } \\
\text { ingredients, especially in plants. Plants that are scientifically proven to have } \\
\text { anti-inflammatory properties, namely turmeric (Curcuma domestica Val.) } \\
\text { The method used in this literature study is a review of various journals } \\
\text { published online, with the keyword turmeric as an anti-inflammatory, } \\
\text { reviewed one by one and then the journals obtained are collected and } \\
\text { information created by summarizing the content and then comparing the } \\
\text { journals to be used as references. The results showed that turmeric tested } \\
\text { had anti-inflammatory activity. The strength of the anti-inflammatory effect is } \\
\text { shown by the carrageenan induction method which inhibits endema in rat } \\
\text { feet and inflammation in the liver using the method of induction by } \\
\text { diethylnitrosamine in this plant varies, depending on the dose. Compounds } \\
\text { that are considered to provide anti-inflammatory activity are curcumin class } \\
\text { compounds because they can inhibit the formation of prostagladin, } \\
\text { thromboxan, and prostagycycline by inhibiting the activity of the } \\
\text { cyclooxygenase enzyme. Curcumin also inhibits the formation of leuketrien } \\
\text { compounds by inhibiting the activity of the lipoxygenase enzyme. }\end{array}$} \\
\hline $\begin{aligned} \text { Keywords: } & \\
\text {. } & \text { Anti-inflamatory } \\
\text { - } & \text { Turmeric } \\
\text { - } & \text { Cucurmin }\end{aligned}$ & \\
\hline $\begin{aligned} & \text { Kata Kunci: } \\
& \text { - } \text { Antiinflamasi } \\
& \text { - } \text { Kunyit } \\
& \text { - } \text { Kukurmin }\end{aligned}$ & $\begin{array}{l}\text { A B S T R A K } \\
\text { Inflamasi merupakan perlindungan normal ketika timbul luka jaringan karena } \\
\text { zat mikrobiologi, zat kimia atau trauma fisik. Efek samping yang ditimbulkan } \\
\text { oleh obat antiinflamasi banyak sehingga dibuat bahan alam untuk } \\
\text { pengembangan antiinflamasi salah satunya adalah tanaman. Kunyit } \\
\text { (Curcumma domestica Val.) adalah tanaman yang memiliki khasiat } \\
\text { antiinflamasi yang terbukti secara ilmiah. Metode yang digunakan adalah } \\
\text { studi literatur dengan kata kunci kunyit sebagai antiinflamasi, diulas satu } \\
\text { persatu kemudian jurnal yang didapat dikumpulkan dan informasi dibuat } \\
\text { dengan merangkum isi lalu membandingkan jurnal yang akan dijadikan } \\
\text { acuan. Hasil membuktikan bahwa kunyit memiliki aktivitas antiinflamasi. } \\
\text { Efek antiinflamasi ditunjukkan dengan metode induksi karagenan yg } \\
\text { menghambat endema pada kaki tikus dan peradangan pada hati tikus } \\
\text { menggunakan metode induksi oleh dietilnitrosamin tergantung dosisnya pada } \\
\text { tanaman berbeda. Senyawa golongan kurkumin merupakan senyawa yang } \\
\text { terbukti memberikan aktivitas antiinflamasi karena dapat menghambat } \\
\text { pembentukan prostagladin, prostagsiklin dan tromboksan dengan cara } \\
\text { menghambat aktifitas enzim siklooksigenase. Aktivitas yang lain dari } \\
\text { kurkumin adalah menghambat pembentukan senyawa leuketrien dengan } \\
\text { menghambat aktifitas enzim lipoxygenase. }\end{array}$ \\
\hline
\end{tabular}




\section{PENDAHULUAN}

Respon protektif setempat yang disebabkan oleh kerusakan jaringan karena trauma fisik, zat mikrobiologi atau zat kimia yang merusak merupakan pengertian dari antiiflamasi. Fungsi inflamasi ada tiga yaitu menghancurkan, mengurangi, atau melokalisasi (sekuster) baik agen yang merusak maupun jaringan yang rusak. Pembengkakan, panas, nyeri, kemerahan dan perubahan fungsi termasuk ciri-ciri antiinflamasi (Manurung dkk, 2016).

Ada dua jenis obat antiinflamasi yaitu antiinflamasi steroid dan nonsteroid. Antiinflamasi nonsteroid dapat menyebabkan tukak lambung hingga pendarahan, anemia, dan gangguan ginjal sedangkan antiinflamasi steroid dapat menyebabkan tukak peptik, osteoporosis, penurunan imunitas terhadap infeksi, atropi otot, meningkatkan tekanan intra okular dan jaringan lemak, serta bersifat diabetik (Lee et al., 2016).

Pengembangan antiinflamasi yang berasal dari tanaman dilakukan berdasarkan efek samping dari obat antiinflamasi. Bahan obat yang dipakai yaitu buah, daun, kulit batang, rimpang dan bunga (Manurung dkk, 2016).

Kunyit (Curcumma domestica Val.) adalah tanaman dari suku Zingiberaceae. Ada 47 genus dan sekitar 1000 spesies Zingiberaceae tersebar di Asia Selatan dan
Asia Tenggara. Spesies dari famili ini banyak dikonsumsi sebagai jamu tradisional. Kunyit (Curcuma domestica Val.) memiliki sejarah panjang dalam sistem pengobatan tradisional (Putri, 2019).

Kurkuminoid (3,0-5,0\%) dan minyak atsiri (2,5-6,0\%) merupakan senyawa utama yang ditemukan dalam rimpang kunyit. Senyawa lain yang terdapat dikunyit adalah kalsium, fosfor, zat besi, pati, lemak, protein, kamfer, gom, damar dan resin (Hartati, 2013).

Berbagai efek farmakologis dari kunyit telah dilaporkan yaitu sebagai antiinflamasi (Shan \& Chu yuan, 2018), antioksidan, antibakteri, antivirus, antifungi, antimalaria, antikarsinogen dan penyembuhan luka. Efek antiinflamasi yang lain yaitu menggunakan tikus putih dengan hasil menurunkan pembengkakan (Meilina \& Rasmadin, 2018).

Dari uraian diatas maka peneliti akan mengkaji tentang "Aktifitas Kunyit (Curcuma domestica Val.) Sebagai Antiinflamasi Ditinjau Dari Berbagai Literatur" yaitu mereview dan membandingkan jurnal penelitian yang berhubungan dengan aktivitas farmakologinya berdasarkan studi literatur 


\section{METODE}

Metode yang digunakan sebagai bahan review jurnal adalah studi literatur. Pustaka yang digunakan merupakan jurnal ilmiah terbitan 10 tahun terakhir dengan tema aktivitas antiinflamasi dari tanaman kunyit. Jumlah jurnal yang digunakan adalah 10 jurnal yang terdiri dari 7 jurnal utama dan 3 jurnal pendukung. Jurnal yang diperoleh merupakan jurnal nasional maupun jurnal internasional yang diterbitkan secara online dari berbagai web jurnal ataupun melaui mesin pencarian berupa google dan melalui situs google schoolar, diulas satu per satu kemudian jurnal yang didapat dikumpulkan dan informasi dibuat dengan merangkum isi dan membandingkan dari tiap jurnal yang akan dijadikan acuan.

\section{HASIL DAN PEMBAHASAN}

Peneliti telah menelaah beberapa artikel jurnal terkait inflamasi. Berdasarkan informasi yang ditemukan pada artikel tersebut didapatkan bahwa respon protektif setempat yang disebabkan oleh kerusakan jaringan karena trauma fisik, zat mikrobiologi atau zat kimia yang merusak merupakan pengertian dari antiiflamasi. Inflamasi terdiri atas inflamasi kronis dan inflamasi akut (Furst et al., 2013). Menurut Manurung (2016), fungsi inflamasi antara lain menghancurkan, mengurangi, atau melokalisasi (sekuster) baik agen yang merusak maupun jaringan yang rusak.

Goodman \& Gilman (2006) menjelaskan bahwa inflamasi adalah reaksi tubuh dari rangsangan merugikan yang disebabkan oleh infeksi, antibodi atau luka fisik. Menurut Barber dan Robertson (2012), inflamasi merupakan respon tubuh terhadap kerusakan seluler. Tujuannya untuk membersihkan dan mempersiapkan jaringan tubuh sehingga bisa membentuk kembali jaringan yang mengalami cedera.

Kandungan Senyawa Aktif Kunyit (Curcuma domestica Val.)

Pada penelitian Anon tahun 2012 dijelaskan bahwa kurkuminoid dan minyak atsiri merupakan kandungan utama yang ada di kunyit. Kandungan kurkuminoid berkisar 3,0-5,0 terdiri dari kurkumin dan turunannya yaitu demekoksikurkumin dan bisdemetoksik kurkuimin. Kurkumin dikenal sebagai kurkumin I, kurkumin II, dan kurkumin III. Pada penelitian Hartati tahun 2013, ditemukan fluoresensi kurkumin berwarna kuning jingga, sampai jingga kemerahan yang kuat di bawah sinar ultra violet yang tidak stabil jika terkena sinar matahari dan stabil apabila dipanaskan. Pada rimpang kunyit juga ditemukan kandungan seperti kalsium, fosfor, zat besi, pati, lemak, protein, gom, kamfer, resin, damar . 
Pada penelitian Erlina tahun 2007, kunyit memiliki aktivitas antiinflamasi karena mengandung kurkuminoid yang dapat menghambat pembentukan prostaglandin dan menekan aktifitas enzim siklooksigenase. Pengujian aktifitas antiinflamasi dengan menggunakan ekstrak etanol kunyit dengan induksi karagenan menunjukkan efek antiinflamasi dimana volume udema rata-rata tikus setiap kelompok zat uji tidak sebesar volume udema tikus pada kelompok kontrol, dosis efektif nya sebesar 1000 $\mathrm{mg} / \mathrm{kgBB}$ dengan persen inhibisi 78,37\%.

Pada penelitian Chuang et al tahun 2000, meneliti kurkumin konsentrasi 200 $\mathrm{mg} / \mathrm{kg}$ atau $600 \mathrm{mg} / \mathrm{kg}$ dapat menghambat peradangan hati yang diinduksi oleh dietilnitrosamin pada tikus secara efektif. Penelitian lain menunjukkan bahwa kurkumin dan senyawa semi-sintetik (natrium kurkuminat, diasetil kurkumin, trietil kurkumin dan tetrahidro kurkumin) mempunyai aktivitas antiinflamasi terhadap edema tikus yang diinduksi oleh karagenan.

Dalam beberapa kasus studi in vitro dan hewan, kukurmin menunjukkan kemungkinan mekanisme antiinflamasi. Kurkumin dapat menghambat sejumlah molekul yang terlibat dalam peradangan termasuk fosfolipase, lipooxigenase, COX2, leukotrien, tromboksan prostaglandin, oksida nitrat, kolagenase, elastase, hyaluronidase, MCP-1, interferoninducible protein, faktor nekrosis tumor, dan interleukin-12. Kurkumin menurunkan katalitik fosfolipase A2 dan fosfolipase C g1, sehingga mengurangi pelepasan asam arakhadonat dari selular fosfolipid. Kurkumin mempunyai efek penghambatan pada aktivitas fosfolipase D. Kurkumin dapat menghambat ekspresi cyclooxygenase-2 (COX-2) (Chu Yuan, Yoppi, 2018).

$\begin{array}{lrrr}\text { Kandungan } & \text { Senyawa } & \text { Aktif } & \text { Kunyit } \\ \text { (Curcuma } & \text { domestica } & \text { Val.) } & \text { sebagai }\end{array}$ Antiinflamasi

Kurkumin dalam terapi antiinflamasi bekerja dengan beberapa mekanisme antara lain menghambat pembentukan asam arakidonat dengan fosfolipid dan menghambat dealkilasi asam arakidonat yang telah dilabel dengan fosfolipid. Selain itu, kurkumin juga dapat menghambat sintesis prostaglandin tertentu dengan menghambat enzim siklooksigenase. Mekanisme aksi kurkumin yang lain yaitu dengan menurunkan sintesis leukotrien dengan menghambat enzim lipooksigenase. Berdasarkan pada beberapa mekanisme tersebut, dapat diketahui bahwa kurkumin dapat menurunkan infiltrasi neutrofil dalam kondisi inflamasi dan menghambat agregasi platelet (Suryani dkk, 2015). 
Metode Pengaruh Pemberian Kunyit (Cucurma Domestica Val.) Sebagai Antiinflamasi

Hasil penelitian Erlina dkk (2007), tikus dikelompokkan menjadi lima kelompok yaitu satu kelompok sebagai kontrol dan empat kelompok lagi diberi bahan uji berupa ekstrak dan satu kelompok sebagai pembanding, volume kaki tikus diukur menggunakan alat pletismometer sebagai volume awal (Vo). Pada kelompok kontrol diberikan suspensi CMC 0,5\%, kelompok pembanding diberikan suspensi asetosal dengan dosis $200 \mathrm{mg} / \mathrm{kg}$ dalam CMC 0,5\%, kelompok bahan uji diberikan ekstrak dosis 100 $\mathrm{mg} / \mathrm{kg}, 250 \mathrm{mg} / \mathrm{kg}, 500 \mathrm{mg} / \mathrm{kg}$ dan 1000 $\mathrm{mg} / \mathrm{kg}$. Semua perlakuan diberikan melalui oral dengan volume $1 \%$ berat badan. Satu jam kemudian tikus diberikan suntikan suspensi karagen $1 \%$ pada telapa kaki tikus secara intrakutan. Kemudian volume kaki diukur lagi setiap satu jam selama 6 jam sebagai volume akhir (Vt).

Pada penelitian Kohli et al tahun 2005 melakukan penelitian dengan metode in vitro dimana dengan kurkumin dalam dosis 100 dan $200 \mathrm{mg} / \mathrm{kg}$ menghambat pembentukan granuloma. Curcumin $(20 \mathrm{mg} / \mathrm{ml})$ serta ibuprofen (2 $\mathrm{mg} / \mathrm{ml}$ ) menyebabkan penghambatan total kontraksi spontan uterus tikus hamil yang terisolasi. Dalam sebuah studi in vivo, COX 2 dalam eksudat inflamasi tikus kontrol dengan peradangan adalah 7,29 $\mathrm{mg} / \mathrm{ml}$. Pengobatan hewan dengan curcumin (200 mg / kg) dan ibuprofen (20 $\mathrm{mg} / \mathrm{kg}$ ) selama 4 hari mengurangi PGE 2 konten eksudat masing-masing sebesar $45 \%$ dan $61 \%$. Dengan demikian, curcumin sama efektifnya dengan ibuprofen dalam menghambat sintesis COX 2 dalam eksudat inflamasi.

Pada penelitian Meilina \& Rasmadin tahun 2018, hewan dibagi dalam lima kelompok, yaitu kelompok kontrol (suspensi CMC 0,5\%), kelompok bahan uji (ekstrak etanol rimpang kunyit dengan dosis 400, 500, dan $600 \mathrm{mg} / \mathrm{kg} \mathrm{bb}$ ), dan kelompok pembanding ( indometasin dengan dosis $100 \mathrm{mg} / \mathrm{kg} \mathrm{bb}$ ). Pada sendi kaki kiri diberi tanda sebagai batas pengukuran volume kaki tikus dan diukur volumenya sebagai volume awal (Vo), kemudian pada masing-masing telapak kaki tikus disuntik secara intraplantar dengan larutan indikator karagenan $1 \%$ dengan volume 0,04 ml. Kemudian tikus diberikan suspensi secara oral sesuai dengan kelompoknya lalu volume masingmasing kaki tikus diukur (Suryani dkk, 2015).

Berdasarkan data penelitian, kunyit memiliki aktivitas sebagai antiinflamasi yang mengandung senyawa aktif kurkumin yang bekerja dengan mekanisme menghambat pembentukan asam 
arakidonat dengan fosfolipid dan menghambat dealkilasi asam arakidonat yang telah dilabel dengan fosfolipid. Selain itu, kurkumin juga dapat menghambat sintesis prostaglandin tertentu dengan menghambat enzim sikloogenase. Mekanisme aksi kurkumin yang lain yaitu dengan menurunkan sintesis leukotrien dengan menghambat enzim lipoksigenase

\section{KESIMPULAN}

Berdasarkan review disimpulkan bahwa dosis tertentu dengan menggunakan hewan percobaan kunyit memiliki aktivitas antiinflamasi karena mengandung senyawa aktif kurkuminoid yang dapat menghambat pembentukan prostagladin, tromboksan dan prostagsiklin dengan cara menghambat aktifitas enzim siklooksigenase. Kurkumin juga menghambat pembentukan senyawa leuketrien dengan menghambat aktifitas enzim lipoxygenase. Metode pemberian kunyit sebagai inflamasi dilakukan secara in vivo dengan metode induksi karagenan selain itu pada penelitian peradangan pada hati tikus menggunakan metode induksi oleh dietilnitrosamin. Penelitian biasanya dilakukan dengan menggunakan kelompok kontrol, kelompok bahan uji, kelompok pembanding dan perlakuan.

\section{DAFTAR PUSTAKA}

Anindita, A Y. 2010. Pengaruh Kebiasaan Mengkonsumsi Minuman Kunyit Asam Terhadap Keluhan Dismenorea Primer pada Remaja Putri di Kotamadya Surakarta. Surakarta : Universitas Sebelas Maret.

Anonymous. 2010. Serial tanaman obat, kunyit, BPOM, Jakarta, Available from Tanamanobat.com/kunyit (diakses tanggal 1 juni 2020)

Barber, P dan Robertson D. 2012. Intisari Farmakologi untuk Perawat. Jakarta : EGC Press. Chang, S J, Chen C J, Tsai F C, Lai H M, Tsai P C, Tsai M H, Ko Y C.

Chuang, SE, Chen, AL, Lin, JK. 2000. Inhibition by curcumin of diethylnitro samine-induced hepatic hyperplasia, inflammation, cellular gene products and cellcycle related protein in rats. Food Chem. Toxicol. 38, p. $991-25$

Chu Yuan, Shan and Yoppi Iskandar. Studi kandungan kimia dan aktivitas farmakologi tanaman kunyit (Curcuma longa L.)." Farmaka 16.2 (2018).

Erlina Rustam dkk (2007). Efek Antiinflmasi Ekstrak Etanol Kunyit (Curcuma domestica val) Pada Tikus Putih Jantan Wistar. Indonesia.

Furst, DE, Urlich, R.W \& Prakash, S. 2013. Anti-inflamasi Non-steroid, Antirematik, Pemodifikasi Penyakit, Analgetik Non-opioid, \& untuk Gout. Dalam: Katzung,B.G. Farmakologi Dasar \& Klinik.Edisi 12 Vol.2. Jakarta: EGC. 
Goodman G. The Pharmacological Basis of Therapeutics; AnalgesicAntipyretic Agents. Edisi ke-12. New York/Toronto: Mc Graw-Hill; 2008. Hal. 959-1000.

Hartati,Sri Yuni. "Khasiat kunyit sebagai obat tradisional dan manfaat lainnya." Warta Penelitian dan pengembangan tanaman industri 19.2 (2013): 5-9.

Kohli K, Ali J, Ansari MJ, Raheman Z. 2005. Kurkumin: A natural antiinflammatory agent. Indian $J$ Pharmacol 37:141-7.

Lee, se-Eun, Lim Cheyeon, Kim Hyungwoo, Cho Suin. 2016. a study of the anti inflammatory effects of the ethyl acetate fraction of the methanol extract of forsythiae fruct us, Afr. J.Tradit. Complement Altern Med. (2016) 13(5):102-11.

Manurung, Nur Ramadhani Maung, and Sri Adi Sumiwi."Aktivitas antiinflamasi berbagai tanaman diduga berasal dari flavonoid." Farmaka 14.2 (2016): 111-122.

Meilina Rulia, Rasmadin Mukhtar "Efek Antiinflamasi Ekstrak Etanol Rimpang Kunyit (Curcuma domestica Val.) pada Tikus Putih yang Diinduksi Karagenan" Journal of Healthcare Technology and Medicine Vol. 4 No. 1 April 2018 Universitas Ubudiyah Indonesia.

Putri Kholilah,Maulida and Bayu Indradi. "Aktivitas Farmakologis Zingiber Officinale Rosc, Curcuma Longa L., Dan Curcuma Xanthorrhiza Roxb." Farmaka 17.2 (2019): 150160.

Suryani S., Wahyuni, W., \& Benny, F. (2015). Uji Efek Antiinflamasi secara In Vivo Nanopartikel Kurkumin yang Diformulasikan menggunakan Metode Reinforcement Gelasi Ionik. Pharmauho: Jurnal Farmasi, Sains, dan Kesehatan, 1(1). 